\title{
A polemical introduction
}

\author{
Nicola McDonald
}

The Middle English romances have been called the 'ugly ducklings of medieval English studies'. ${ }^{\mathrm{I}}$ In a discipline that contests even the most basic definition of the genre, romance's low prestige is one of the few critical certainties. Despite its status as medieval England's most popular secular genre (more than one hundred romances are extant), the origin of the modern novel (still the most significant literary form), the ancestor of almost all contemporary popular fiction (in print and on screen) and the most audacious and compendious testimony to the imaginary world of the Middle Ages, Middle English popular romance remains, with rare exceptions, under read and under studied. Popular romance is the pulp fiction of medieval England, the 'principal secular literature of entertainment' for an enormously diverse audience that endures for over two hundred and fifty years. ${ }^{2}$ It is fast-paced and formulaic; it markets itself unabashedly as genre fiction; it is comparatively cheap and, in performance, ephemeral; it has a sensationalist taste for sex and violence; and it seems content to reproduce the easy certainties of sexist, racist and other bigoted ideologies. But this is not a reason to dismiss it. On the contrary, popular romance provides us with a unique opportunity to explore the complex workings of the medieval imaginary and the world outside the text that feeds and supports it.

The purpose of this collection of essays, all specially commissioned for this volume, is to demonstrate that popular romance not only merits and rewards serious critical attention, but that we ignore it to the detriment of our understanding of the complex and conflicted world of medieval England. Each essay concentrates on a single Middle English popular romance that has so far received little critical attention; together they exemplify, but by no means exhaust, both the 
richness of the primary material and the range of critical analysis that the genre invites. Contributors have been asked to provide relevant introductory material (including date of composition, extant manuscripts, and a plot summary) in order to make these neglected texts accessible to a non-specialist audience, but the focus of the essay is a sustained argument that demonstrates that the romances invite innovative, exacting and theoretically charged analysis. Readers will notice that the essays do not support a single, homogeneous reading of popular romance; in other words, this volume's authors work with assumptions and come to conclusions, about issues as fundamental as the genre's aesthetic codes, its political and cultural ideologies, its historical consciousness, that are different and sometimes opposed. This is a sign of healthy scholarship and of the vitality of the field of inquiry.

As an introduction to the ten essays that comprise this book, I provide neither a historical overview of the genre (authorship, audience, manuscripts) nor a survey of the different theoretical approaches that help elucidate the workings of popular culture; both of these have recently received admirable treatment elsewhere. ${ }^{3}$ Instead, I offer a short polemical essay that confronts head-on the paradox that informs and ultimately circumscribes all of our thinking about Middle English popular romance. 'Popular' in its capacity to attract a large and heterogeneous medieval audience, as well as in its ability to provide that audience with enormous enjoyment, romance's popularity is likewise what excludes it from serious and sustained academic consideration: judged low-class, on account of its non-aristocratic audience, its reliance on stereotypes, formulae and conventional plot structures, and its particular brand of unadulterated good fun, criticism repeatedly dismisses these narratives as unworthy of the kind of close reading, as well as historically and theoretically informed analysis, that we regularly afford so-called elite medieval English art (in particular, but not limited to, Chaucer, Langland and the Gawain-poet). There are of course exceptions to the general trends I identify below; not all readers vilify popular romance, its readers or its aesthetic, but the tenacity with which the received denigration of romance, much of it traceable to outdated standards of aesthetic judgement and intellectual elitism, not only holds but continues to shape the field of inquiry, is nothing short of remarkable. The introduction is divided into two sections that tackle in turn what I think is at stake in our appreciation and enjoyment of these inescapably popular narratives: romance's status as a socially and aesthetically degenerate form of fiction and its capacity to generate textual pleasure. Not everyone will agree with it, but if it 
stimulates debate about popular romance it will have more than served its purpose.

\section{Dangerous recreations}

Medieval romance shares with other incendiary fictions a reputation for subverting social and moral order: indecent, unorthodox, criminal; and like these works its consumption has been policed. Romance, so its censors insist, perverts the mind; it incites illicit thought, obscene behaviour, and a propensity for violent action. Reviled by the medieval church as 'vayn carpynge', foolish and corrupting lies, and dismissed by men with literary pretensions (like Harry Bailey) as 'nat woorth a toord', romance becomes, in the centuries following its invention, the subject of energetic condemnation, a byword for moral degeneracy, religious heresy, political tyranny and everything that's bad about fiction. ${ }^{4}$ John Florio (translating Montaigne) judges the whole corpus 'a wit-besotting trash of bookes', while the antiquarian Thomas Percy, at once apologist and bowdleriser, admits that they 'would do hurt' to 'common Readers'. Juan Luis Vives, the Spanish humanist and friend of Sir Thomas More, in a sweeping prohibition of romance, outlines its dangers more precisely: 'they make them [men and women] wylye and craftye, they kindle and styr up couetousnes, inflame angre, and all beastly and filthy desyre'. England's Roger Ascham likewise warns of social mayhem: 'a man by redinge [romance], shulde be led to none other ends, but only manslaughter and baudrye'. James Beattie concurs: 'Romances are a dangerous recreation', they 'corrupt the heart', 'stimulate the passions' and fill the mind with 'criminal propensities'. These critics (medieval ecclesiast, early humanist, eighteenth-century antiquarian and beyond), whether moralists, educators or simply middle-class men determined on social advancement, are keen to protect readers from the kind of depravity that texts like Guy of Warwick, Libeaus Desconus or Ipomadon necessarily engender. The outrage and invective that romance inspires - from men who are bound neither by country nor century - is barely distinguishable from the rhetoric of interdiction that continues to characterise the procensorship lobby today.

The early critics of romance, insistent on the genre's disruptive potential, have been treated by modern scholarship with a mixture of disdain and humorous detachment. ${ }^{6}$ Given its diminished modern status, we simply cannot believe that medieval romance bears worrying 
about; it no longer attracts enough attention to merit public disapprobation, be it moral, political or cultural, let alone to excite the censors. Relegated along with most other medieval English literature, by the relative obscurity of its language, to an almost exclusively academic audience, its consumption is policed only by critical fashion. And for a long time now, romance - at least Middle English popular romance has been unfashionable. I recall romance's history of censorship not only because it testifies to the enormous popularity of these narratives, (whether in the original Middle English or in modernised and abridged versions) from the late Middle Ages to the nineteenth century, nor simply because it demonstrates their inherent unorthodoxy (a point to which I will return below), but because, despite differences in tone and rhetoric, it is animated by the same assumptions and anxieties that determine popular romance's degraded academic status.

Scholars long ago remarked that the objections voiced by the humanists, as well as eighteenth-century men of taste and others like them, are based primarily on romance's distance from the newly discovered and celebrated forms of classical poetry. As such they are more indicative of post-medieval prejudice, about everything from social class to Catholicism, than anything inherent in the medieval genre. And it is precisely these inherited distinctions that we, informed by the insights of post-structuralist thought, have learned to interrogate. Yet, popular romance has hardly benefited from the collapse of the traditional hierarchies of aesthetic (and with it academic) judgement. There must be many reasons why. The slowness with which medieval English studies has responded to developments in contemporary critical thought is undoubtedly a key factor; but, given that the recent surge in theoretically informed medieval research remains unmatched in romance scholarship, it cannot be the only one. I want to propose that the problem with popular romance is not, contrary to expectation, its opponents (whose invective invites rebuttal) but rather its friends.

Ad Putter and Jane Gilbert have already suggested that 'embarrassment' explains the 'predominance in romance studies of scholarship on manuscripts, editorial problems, and textual history'; this kind of work does not demand aesthetic judgement and so is never required to confront the texts' reputation as 'poetic disasters'. Implicit in Putter and Gilbert's comment is the sense that, despite its evident industry, such scholarship has simultaneously done the genre a disservice. I think they're right; but I want to propose that romance scholarship is informed by something that is more damaging than a sin of omission. 
From its inception, scholarship on the Middle English popular romances has been characterised by a thinly - if at all - veiled repugnance to the romances themselves, not only to their poetic form but their subject matter and the medieval audience who is imagined to enjoy them. As Arthur Johnston has demonstrated, it is in the middle of the eighteenth century, with the publication of the first modern editions, that the study of Middle English romance is born; more recent analysis by John Ganim, Nick Groom and David Matthews has exposed the ideologies latent in much of that early work and I build on their insights. ${ }^{8}$ Thomas Percy, antiquarian and arriviste, and his spectacularly successful Reliques of Ancient English Poetry, published first in I765, signals the start of modern abuses of romance. The 'seminal, epoch-making' work of English Romanticism, Percy's Reliques along with his infamous Folio manuscript and the attention they both excited - has made an indelible mark on the way popular romance continues to be read. ${ }^{9}$

Four years after the publication of the Reliques, a three-volume work comprising mainly Middle English ballads and a set of four critical essays including one 'On the ancient metrical romances', Percy recorded on the inside cover of his Folio manuscript the following account of its discovery:

Northumberland House, November 7th, I769.

This very curious Old Manuscript in its present mutilated state, but unbound and sadly torn \&c., I rescued from destruction, and begged at the hands of my worthy friend Humphrey Pitt Esq. ... I saw it lying dirty on the floor under a Bureau in the Parlour: being used by the maids to light the fire. It was afterwards sent, most unfortunately, to an ignorant Bookbinder, who pared the margin, when I put it into Boards in order to lend it to Dr. Johnson.

The son of a provincial grocer and born Thomas Piercy, the editor of the Reliques, armed with a self-fashioned aristocratic pedigree and the patronage of his wealthy namesake, was by I769 well advanced in what was to be, thanks to the Reliques' popular success, a starry church career. ${ }^{I I}$ Whether or not Percy's narrative is true - it bears striking resemblance to a number of stories concerning the rescue of early manuscripts circulating at the time - is irrelevant; what is more significant is how, at a distance of more than ten years from its acquisition, he constructs his relationship to the source of his hard-earned success. The Folio, an artefact that Percy jealously guarded like a personal 
fetish, is mutilated and dirty, abused by serving women and damaged by a tradesman. Its physical and social dereliction opposes, and is used to confirm, Percy's own social and intellectual status, on a par with the titled Northumberlands (with whom he shares the estate) and the celebrated Dr Johnson (with whom he fraternises). Percy's embarrassment with his medieval relic and with the volumes of poetry that issued from it and the other dilapidated manuscripts he consulted, something he excuses in a later letter to John Pinkerton as the 'follies' of 'my youth', ${ }^{12}$ was to become so intense that by the time he was confirmed as Lord Bishop of Dromore he refused to sign his name to the Reliques' fourth edition; a nephew, conveniently called Thomas Percy, stepped into the breach. What Percy's narratives (the stories he inscribes on his manuscript and in the trajectory of his own career) demonstrate is the tenacity with which the taint of the popular clings to these medieval texts: the brutish and illiterate medieval that is imagined to engender romance (Percy calls it 'gross and ignorant' ${ }^{\mathrm{I} 3}$ ) is neatly replaced with a no less repugnant, but more reflective of eighteenth-century preoccupations, world of service, trade and dirt. Percy, like later romance amateurs (and later still professionals), is required to establish a distance between himself and the medieval texts in order not to be tarred with the same brush. Ironically, the very success of the Reliques with an ever-widening eighteenth-century audience reinforces its inherent vulgarity and simultaneously threatens Percy's social, and intellectual, integrity. When Vicesimus Knox congratulates Percy on rescuing this popular poetry 'from the hands of the vulgar' and obtaining for it 'a place in the collection of the man of taste', he means it literally: ${ }^{14}$ Percy effectively snatches the Folio from the maids and enshrines it (the religious connotations of Reliques are doubtless purposeful) in the best way an eighteenth-century aspirant gentleman knows how. Percy's Reliques, packed full with the 'barbarous productions' of 'unpolished ages' as its Dedication promises, excites its editor and the public more because of its grotesque curiosities than in spite of them. ${ }^{15}$

Certainly, I am being hard on Percy; he is neither unique, nor uniquely at fault. The Reliques, and with it Percy's ideas about romance, reflect its editor's personal anxieties and aspirations, but it is equally the product of an eighteenth-century antiquarian culture that exploits the past, as well as other peoples and cultures, as a confirmation of its own superiority and achievement. The printing and publication of the Reliques, a process that took three years and that saw Percy publish work on Chinese, runic and Hebrew poetry and fantasise about an 
international volume comprising, in addition, ancient Arabic, Indian, Peruvian, Lapp, Scottish and Greenland poetry, ${ }^{16}$ is coincident both with England's emergence, at the end of the Seven Years' War, as Europe's dominant colonial and commercial power and with a domestic rage for primitive poetry that cannot be disinterested. Percy drew inspiration from, but also fuelled, English fascination with the primitive. ${ }^{17}$ Along with men like Thomas Warton and Richard Hurd, both of whom read romance (although Hurd reads very little) as a function of their interest in Spenser, Percy promotes the Middle Ages as an age of romance, wild with imagination but, in perfect antithesis to his own eminently tasteful time, irredeemably barbarous; at the same time he promotes himself as someone able to know the difference. Where Percy encapsulates all of the ambivalence that distinguishes eighteenthcentury readings of romance, his real importance for later scholarship despite the fact he never completed his own proposed edition of the romances - lies in the longevity of his influence on those who continue to champion the genre.

Four editions of the Reliques were printed in Percy's lifetime, at least twenty-three in the nineteenth century, and the volumes continue to be reprinted (picked up by Everyman in I906) well into the twentieth century. ${ }^{18}$ But Percy's influence on the culture of reading Middle English romance is finally too amorphous to support any simple narrative of direct literary descent. Percy's judgements on romance, its authors and audiences, and the assumptions they entail - evident in his published work as well as his copious correspondence (Warton's opinion of romance, for instance, as espoused in his History of English Poetry, is enormously indebted to his exchanges with Percy) - are elaborated and modified by subsequent generations of readers in a web of intertextual relationships that cannot be rationalised. George Ellis' three-volume Specimens of Early English Metrical Romances - important for being the first published anthology of romance, a mix of prose summary and illustrative quotation - bears Percy's imprint everywhere, nowhere more so than in the invidious relationship between the reader and the romances that Ellis finds necessary, time and again, to reiterate. ${ }^{19} \mathrm{He}$ mocks their long-winded plots, ludicrous emotions and general absurdity, retelling romances like Guy of Warwick and Amis and Amiloun, with the kind of smug irony that is designed only to assert his, and his reader's, superiority over the imagined and denigrated medieval. Ellis, a comfortably off gentleman and sometime diplomat who fraternises with 'princes wits [and] fine ladies', has none of Percy's social anxiety; ${ }^{20}$ he uses the romances instead as a butt for his wit, a 
testament to a kind of social elegance that is best expressed in droll conversation and barbed quips. When Southey remarks that there is 'something in his manners' that shows it is 'a condescension in him' to edit his Specimens, he inadvertently identifies an attitude that is characteristic of all conventional scholarship on the popular romances. ${ }^{21}$

Whether we are talking about the work of Walter Scott (whose recollection of reading Percy as a boy in the mid I780s confirms the logic that identifies romance with childish intellects) or W. R. J. Barron (whose I987 English Medieval Romance, a volume that treats English romance as derivative and finally second-rate, remains the most comprehensive modern analysis of these narratives), popular romance is invariably positioned against something that is judged to be superior; what that something is - epic, French romance or simply good taste changes in accordance with prevailing prejudice and fashion, but the direction of comparison, whereby popular romance is denigrated, never varies. Scott, so often classed among romance's more persuasive advocates, posits in his essay on 'Romance', written for the first supplement to the Encyclopaedia Britannica (I 824), that romance is precisely everything that epic - distinguished by its 'due proportion', 'force', 'precision', 'taste' and 'genius' as 'art' - is not: 'when a story languishes in tedious and minute details' and relies for its interest on 'wild excursions of unbridled fancy' rather than 'the skill of the poet', then its author is 'no more than a humble romancer'. Scott here mimics the rhetoric of neo-classical distinction, but his particular prejudice, inseparable from his social aspirations (like Percy he is a man on the make), comes into focus when he imagines the medieval audience 'circumscribed in knowledge' and 'limited in conversational powers': 'to prevent those pauses of discourse which sometimes fall heavily on a company', a poet-minstrel is employed, he argues, to supply 'an agreeable train of ideas to those guests who had few of their own'. ${ }^{22}$ From Scott we learn less about medieval romance than about the imperative of polite conversation that exercises the nineteenth-century host, just as later we learn more from W. P. Ker about Victorian antipathies toward the world of manufacturing: 'hot, dusty and fatigued', romance has 'come through the mills' of men 'who know their business, and have an eye to their profits'. ${ }^{23}$

So far, I have demonstrated only that invidious distinction, reflective of an overt discomfort with the low social status of popular literature, real or imagined, is the hallmark of early (by which I mean pre-twentieth-century) scholarship on the popular romances. Men like Percy, Scott, and even Ker, who write in an idiom markedly 
different from our own, are easy targets for modern scholars keen to demonstrate the superiority of their own brand of criticism. But criticism, even when couched in the familiar terms of a shared professional discourse, is of course never free of its authors' preoccupations and assumptions. What is so remarkable about the modern treatment of popular romance, especially in the work of the genre's putative (and influential) friends, is its duplication of the interests, and prejudices, of its antecedents. Pearsall's scathing denunciation of the romances - 'it is ... difficult to understand why poems that are so bad according to almost every criteria of literary value should have held such a central position in the literary culture of their own period'24 - not only replicates eighteenth-century aesthetic assumptions about popular romance, but the social prejudice that fuels those assumptions. Aesthetic judgement is here indistinguishable from a preoccupation with social class and, finally, secondary to that preoccupation. Indeed, the logic of aesthetic distinction that Pearsall posits is explicitly predicated on the class affiliation of the original audience he assumes for each romance (and vice-versa). As the 'emergent bourgeoisie' (alternatively 'lower or lower-middle-class') - for whom the 'outright vulgarisation' of French romance is originally produced - becomes less emergent, the romances are likewise described as more sophisticated: 'witty, smooth, [and] enormously leisurely'. Aberrantly 'crude' products of this later period are attributed to 'the lowest classes of society' because, according to this scheme of things, they can belong nowhere else. The composerpoets are similarly stigmatised: while low-class romances are 'knock[ed] together' (the association with manual labour is inescapable), superior ones are said to issue from those with intimate knowledge of 'upperclass life'. ${ }^{25}$ Pearsall, like Percy, is of course not alone; in fact, the identification of modern denigrations of romance with individual scholars erroneously suggests that the phenomenon is limited, and limitable, to a few key works or authors. Rather, it so pervades academic discourse, whether in print or informal conversation, that the identification of 'the general run' of romance as 'rustic', 'primitive' or 'amateurish', the product of (and for) 'social aspirants' who 'lack understanding' of 'their social superiors', is commonplace. ${ }^{26}$ Contemporary (and widespread) assumptions that popular romance is a degraded and degenerate form of literature, the product of 'hacks' who 'ransack' aristocratic sources and treat them with 'outrageous violence' confirm Pierre Bourdieu's conviction that academic distinctions 'fulfil a social function of legitimating social differences' ${ }^{27}$ What the study of popular romance demonstrates is the extent to which contemporary 
medieval scholarship - whether as a result of its embattled status in the academy or simply because of the academic's inherent need to assert his or her own intellectual superiority - is threatened, whether consciously or not, by the 'great mass' (as Barron calls $\mathrm{it}^{28}$ ) who is able to enjoy popular romance.

\section{blys, ioye and mykyll myrght: the pleasures of romance}

If scholarship is distrustful of the assumed vulgarity of the Middle English popular romances - a function, as the term implies, of their low social status and denigrated aesthetic (factors that, I have argued, are indistinguishable) - it is equally discomforted by the way that medieval, as well as modern, audiences derive evident, and enormous, pleasure from these narratives. One of the ironies of English romance studies is that the genre's harshest critics are simultaneously those who have an enormous personal investment in the very popularity that they denounce. Percy, for all of his apologetics, patently enjoys popular romance - the 'levities' of his youth ${ }^{29}$ - and he devotes considerable energy and intelligence to his scholarship. His repudiation of the romances, effected as an assertion of his own good taste and critical acumen, is simultaneously the response of a protestant clergyman ill at ease with such a public testimonial to his private pleasures. Percy's fear of censure from his 'graver brethren', alluded to in his private correspondence, is indicative of the kind of anxieties that persist today. ${ }^{30}$ In her provocative essay on 'enjoying the Middle Ages', Louise Fradenberg posits that the preoccupation with 'utility' and 'necessity' in humanities departments (fuelled by the increasing pressure to justify the humanities as economically productive and publicly useful, as well as by the 'ambivalence about enjoyment' characteristic of influential critical schools - she focuses on the Marxist and feminist) is explicitly opposed to the enjoyment of medieval culture. Although medievalists know, she asserts, that 'the pleasure of knowledgeable discourses on pleasure' is what we 'deliver to our audiences', we have assumed as our 'ethical task' to 'discipline' enjoyment out of academic inquiry. In other words, medieval studies (as a modern academic discipline) has invested medieval culture with a seriousness (what Fradenberg calls 'an ethos of pietas') that marginalises or denies those aspects of the culture that are predominantly productive of enjoyment. ${ }^{31}$ So far as popular romance is concerned (a genre Fradenberg does not consider directly), I think she is right. 
Manuscript evidence - unmatched, in the sheer number of surviving texts, by any other secular genre - attests not only to the social and geographical diversity of romance's medieval audience, but to the genre's capacity to generate desire for its distinctive form of narrative and with it the pleasure of gratification: romances written in the thirteenth century continue to be copied into the fifteenth century, while the persistent demand for yet more romance guarantees the production of new texts well into the renaissance. Modern scholars are likewise keen to confirm that Middle English romance flourishes because of its capacity to 'delight' or 'entertain' - in other words to provide enjoyment for - its audience. ${ }^{32}$ Yet, it is precisely this popularity (the genre's capacity to be well liked) that impedes critical appreciation not only of the romance aesthetic, but of its ideologies and of the kinds of readings it can sustain. David Benson (writing about the Seege of Troye) sums up dominant attitudes to the genre as a whole: 'entertainment for the common folk', popular romance is 'disqualified from claiming the attention of any serious audience'. ${ }^{3}$ The kind of pleasure that is generated by Middle English romance is constructed by modern scholarship as second-rate (both 'entertain' and 'delight' are purposefully condescending) and it is set in opposition to the apparently superior gratification derived from the supreme products of [the] age'. ${ }^{34}$ We need to remember, of course, that these distinctions (between the enjoyment afforded by popular romance and the sublimated gratification of so-called elite medieval art) are at least as indicative of the need for academic self-legitimation and selfperpetuation as of anything intrinsic to romance or its production of pleasure. Academic communities have long been resistant to popular art and to the kind of pleasure it produces; the denial of 'lower' forms of enjoyment (musicals, Hollywood films, pulp fiction) is one of the most important ways in which consumers and critics of high culture (opera, art-house cinema, the post-modern novel) assert their cultural credentials and intellectual credibility. ${ }^{35}$ What then is something endemic to academic study is today exacerbated and, despite growing theoretical interest in popular culture, perpetuated by what Fradenberg identifies as the prevailing seriousness (or ethos of pietas) that drives most modern research on the Middle Ages. Because popular romance makes explicit its commitment to its audience's pleasure and because it is structured to gratify that pleasure, it fails to attract the kind of high profile attention (by academics and their publishers) that has recently been accorded medieval texts (the Book of Margery Kempe or Hoccleve's Regiment of Princes, for instance) that, once as little regarded 
as popular romance, are now judged 'serious' because they more readily (or obviously) coincide with the agendas that propel academic study.

Key to modern scholarship's ambivalence about the kind of pleasure that popular romance generates is the assumption that it is passive, a pleasure that comes from the consumption, without thought or agency, of standardised products that espouse normative ideologies. Although critics are quick to disparage the aesthetics of popular romance as 'rustic' or 'primitive', a sign that it issues from the 'great mass' who is incapable of understanding or appreciating the aesthetics of the elite, its ideologies (of gender, social class, race, religion and so on) are assumed not to challenge but rather to mimic those of that same elite. Popular romance, in other words, loses on both counts degenerate in form and style it has none of the disruptive potential that is commonly attributed to the degenerate - and its pleasure, by all accounts banal, is refigured as form of coercion: sated with the kind of gratification that the genre provides (usually in the form of wish fulfilment), the audience is contentedly complicit in its own oppression. The view that popular culture serves as an opiate is widely held by critics who otherwise adhere to divergent theoretical schools. Its broad appeal is in part attributable to the way in which it replicates the distinctions upon which academic inquiry is built: the critic knows an opiate when s/he sees one - the masses apparently don't - and the critical act is validated by its exposure (invariably expressed in terms of 'us' and 'them') of the ideologies that oppress the unwitting consumer. ${ }^{36}$ Popular romance can and does replicate dominant ideologies; socalled elite art, despite what we imagine is its inherently radical potential, likewise does so all the time. Not all dominant ideologies, however, are equally opposed to the disparate interests of the popular audience: the audience of Middle English romance is at least as heterogeneous (in terms of age, gender, wealth, social rank, education and regional affiliation) as it is homogeneous. And indeed, the individual members of that audience are just as likely as we are to have complex wants and needs that they will seek to satisfy in different, and sometimes contradictory, ways. But more importantly, popular culture (and with it popular romance) is not simply, as its detractors would have us believe, an instrument of social control - popular romance is too diverse a genre to support such reductive analysis - and neither is its audience made up solely of dupes. Popular romance is rather a space, narrative as well as imaginary, in which cultural norms and divergences from those norms are negotiated and articulated. ${ }^{37}$

I want now to look more closely at the kind of pleasure - what the 
medieval poet designates 'blys', 'ioye' or 'mykyll myrght' $3^{8}$ - that is produced by popular romance. More than any other medieval genre, the Middle English romances are exemplary of what modern narratologists call 'narrative desire'. ${ }^{39}$ They are predominantly stories about desire: in the simplest terms, the protagonist's desire for something for instance, a husband, wife or lover, wealth, property or status (expressed as a family or knightly identity) - and the satisfaction of that desire. The plot is regularly complicated by the proliferation of desires that are sometimes incompatible - unwanted amorous advances are repulsed; a couple's desire for an heir gives way to the heir's own desires; misplaced desire is redirected to more appropriate ends - and the protagonist usually discovers that the satisfaction of one desire (for a wife, for instance) guarantees the satisfaction of others (for material wealth, status, property). Just as importantly, however, they are also stories in which desire functions as what Peter Brooks calls the 'motor force' of narrative..$^{40}$ At the start of virtually every romance a desire is present, usually in a state of initial arousal, that is so intense (because thwarted or challenged) that action - some kind of forward narrative movement designed to bring about change - is demanded. Sexual desire (whether wanted, unwanted or feared) is one of the most common initiatory devices, but a desire for offspring, material wealth, a lost identity, political or religious dominion, or simply aventure are equally effective as a way of getting the story off the ground. This desire, like all desires, is structurally end-oriented. In other words, it gives to narrative the textual energy that propels the plot forward in search of satisfaction; it pushes the protagonist through or around the obstacles that delay the achievement of desire. Modern narrative is often distinguished by the way in which it frustrates the conventional trajectory of desire, pulls it up short and resists the closure that is otherwise, in narrative terms, inevitable. Our desires, such narratives contend, are not finally satisfiable; indeed, desire is a perpetual want whose very resistance to satisfaction exposes the inescapable fictionality of stories that do close with desire's gratification. Of course such resistance to closure is not limited to modern literature, far from it. But it is wholly at odds with what we find in the popular romances. The kind of desire that propels popular romance always finds satisfaction. Aventure, the essence we are told of romance, presumes in fact an unfolding of narrative that - because it is literally advenire, 'to arrive at' or 'to reach' - is inescapably mindful of its end. As the reworking of the Orpheus story demonstrates, Eurydice must - because Orpheus' desire for her is what animates the narrative - be reunited with her husband, even if 
the sources have to be changed to accommodate the new happy ending. The pleasure of romance is found then not simply in the gratification of desire (the desire of audience and protagonist may coincide, but it is not necessary), but in the way that desire is played out: in the way expectations are raised, challenged (by a series of apparently insurmountable obstacles), and then finally satisfied. The perfunctory nature of most romance conclusions (lovers are united, families reunited, status achieved, and wealth, property, dominion secured all in a few short lines) is indicative of their necessity (although short they cannot be omitted), but also of the fact that the narrative's energy, and with it its pleasure, is predominantly elsewhere.

The blatant artifice of the happy ending is one of the more obvious ways in which popular romance exposes the mechanics of its construction. Formulaic diction, stock motifs, repetition and recapitulation of key events and themes, intertextual dialogue (with other romances) and citation of bookish sources all serve to remind the audience that the romance is the product of a textually informed redactor, that this is a story and that someone has skilfully constructed it. The sharply demarcated ending - coincident with the gratification of desire and usually furnished with an explicit (for instance, 'here endeth', 'Amen') that simultaneously underscores the text's allegiance to other forms of fiction ('lay', 'rime', 'song' etc.) - is paired with an equally artificial beginning that likewise serves to promote the narrative as a romance, that is, as a story that adheres to, and makes sense within, established fictional codes. The prominence of references to oral performance, the subject of so many debates about the transmission and reception of the romances, indicates most importantly the way in which the text establishes its relationship with its audience as a purposefully shaped narrative driven by the story-teller's 'I' ${ }^{4 I}$ Part of romance pleasure is, undoubtedly, derived from the genre's status as a collective fiction: the audience participates in a shared imaginative experience that both presupposes a community of listeners (whether that community is a real, aural one or a disparate group of readers does not matter) and grants access to that community through a mutual familiarity with the codes that shape and give meaning to the romance story. But the way in which popular romance flaunts its status as fiction points to another kind of pleasure. And that is the pleasure of fiction.

Fiction, however imperfectly, takes its audience outside of the norms and conventions that structure everyday life; this may simply be a liberation from real-time and real-space, but equally it provides an opportunity for the radical formation of new times and spaces. 
Fictional worlds necessarily have limits - the limits of what is (for audience and author) possible - but, generally speaking, the more flagrantly a text promotes itself as fiction, the greater are its opportunities to test precisely those limits. The otherworlds of medieval romance have long been recognised as a distinctive feature of the genre and indeed they are often credited with its popular appeal. The world of faerie replete with its magic rings, fairy mistresses and love potions - and the forest - home to dragons, giants and other monstrous creatures - are commonly identified as archetypal romance spaces, but equally, if not more, typical of romance is the imaginary space it generates simply by insisting that it is a fiction. Within the circumscribed space of the narrative, both author and audience are freed from the exigencies of daily life not just so that they can escape the world they know (magic operates only in a minority of the Middle English popular romances and likewise forests are not obligatory), but so that they can explore to test, to defy, to confirm - the principles by which it operates. Although invariably located in an elite aristocratic milieu (from whence neither author not audience is likely to issue), these narratives treat of subjects like courtship and marriage, domestic violence, political and social authority, ethical conduct, national identity and religious faith that are germane sometimes to daily life, sometimes to the fantasies and anxieties of that life in extremis. And they treat of them in ways that, because the text is rigidly structured to gratify narrative desire (because it constantly assures us it is a fiction), are all the more provocative, all the more conducive to our discovery of the limits - both where they are and where they aren't - of the world in which we live. What so distinguishes popular romance as a genre is the way in which it forges its meanings out of the clash between the marvellous and the mundane. Because the narrative necessarily achieves satisfaction (the knight wins the lady, the Christian wins victory) and because satisfaction is always, for an audience who knows how romance works, a foregone conclusion, there are few limits to what can take place en route to satisfaction: nuns are raped, virgins stripped naked and whipped, mothers are mutilated by their sons, apes abduct small boys and knights feed with dogs, infants are slaughtered by their parents, Christians eat Saracens, the list goes on. But because that satisfaction is so selfconsciously, so overtly fictional, the narrative, with all of its extraordinary twists and turns, can never finally be reduced to the simple certainties (young girls will escape their incestuous fathers, the rightful heir will inherit unjustly lost property) that its end embodies. In other words, the structure of romance is too rigid to contain the complexities and 
effusions of its narrative; and that is why we enjoy it so much.

Popular Middle English romance locates itself precisely at the juncture that Barthes identifies as the ultimate site of textual pleasure or what he calls jouissance (a term whose meaning encompasses enjoyment, bliss and sexual pleasure): ${ }^{42}$ between conformity and rebellion, between the kind of narrative order that finds resolution in the inviolable happy ending and the chaos that is threatened by the giants and rapists, incubi, cannibals and necrophiliacs, to say nothing of the abusive parents and their wild offspring, who roam the romance landscape. Narrative pleasure is produced by, and in, the gap that exists between the conventions that structure romance (the use of stock characters, formulaic language as well, of course, as the social and cultural norms that are omnipresent) and the transgressions that its narrative produces. The prevalence of convention in romance is integral to the kind of pleasure it achieves; without convention (without a system of norms and expectations that can be transgressed), the effect of transgression is lost. And it is in this effect that pleasure is located. It is only when romance establishes, for instance, the importance of female chastity that there is any stake in trying to defend it; but once the import of chastity is established, then the narrative can get on with the business of violating it. The pleasure of this kind of narrative is primarily located not in the final preservation of chastity (which, if it occurs, is always treated perfunctorily and with blatant artifice), but in the interplay, or more violently in the collision, of transgression (rape, incest, or other sexual perversions) and convention (female chastity).

Narrative order might well be able to achieve textual resolution, to forge normative solutions out of the capacious desires that animate popular romance, but it can never efface the transgressions that ultimately generate the narrative and the pleasure that the audience finds in it. Popular romance is (despite its predilection for the happy endings that seem to confirm social norms and dominant ideologies) an imaginary space - I would argue the pre-eminent imaginary space in medieval English literature - in which the transgression of cultural boundaries is both embodied and explored; this transgression is sometimes punished, sometimes rehabilitated, and sometimes accommodated, but it is never repressed. And it is with this in mind that I want to return for a moment to the anxieties that exercised romance's early detractors: popular romance, put simply, is a dangerous recreation. Despite the gulf that inevitably separates us from these medieval narratives, they retain the power to shock us, to unsettle our assumptions about, among other things, gender and sexuality, race, religion, 
political formations, social class, ethics, morality and aesthetic distinctions. As scholarship's ongoing discomfort with popular romance - its audience, its aesthetic and its pleasures - demonstrates, we cannot dismiss these texts as crude, second-rate narratives that unquestioningly reproduce established ideologies. Popular romance remains a collection of 'dirty books', where 'dirty' signifies not simply sexually explicit, obscene or morally repugnant, although romance can be all of these things, but that which is essential to all provocative literature, the interrogation of the norms that order and regulate our lives.

\section{Notes}

I am grateful to Alastair Minnis, Felicity Riddy, Hélène Tronc and the Press's readers for advice and critique and for their unfailing support for Pulp fictions.

I Stephen Knight, 'The social function of the Middle English romances', in D. Aers (ed.), Medieval Literature: Criticism, Ideology and History (New York, I986), pp. 99-I22 (p. 99).

2 Derek Pearsall, 'Middle English romance and its audiences', in Mary-Jo Arn and Hanneke Wirtjes (eds), Historical and Editorial Studies in Medieval and Early Modern English for Johan Gerritsen (Groningen, 1985), pp. 37-47 (p. 42).

3 See Ad Putter and Jane Gilbert (eds), The Spirit of Medieval English Popular Romance (Harlow, 2000), pp. I-38.

4 William of Nassington, Speculum Vitae, cited in G. R. Owst, Literature and Pulpit in Medieval England (Oxford, I96I), p. I3; Geoffrey Chaucer, Riverside Chaucer, ed. Larry D. Benson et al. (Oxford, I988), Canterbury Tales VII, 930.

5 The Essayes of Michael Lord of Montaigne, 2 vols, trans. John Florio (London, I603), vol. 2, ch. 25; The Correspondence of Thomas Percy and Richard Farmer, ed. C. Brooks (Baton Rouge, LA, I946), p. 7; The office and duetie of an husband made by the excellent philosopher Lodouicus Viues, trans. T. Paynell (London, I 546); Roger Ascham, 'Toxophilus', in English Works, ed. W. A. Wright (Cambridge, 1904), p. xiv; James Beattie, 'On fable and romance', Dissertations Moral and Critical, 2 vols (Dublin, I783), vol. 2, p. 320.

6 See for instance, C. S. Lewis, English Literature in the Sixteenth Century Excluding Drama (Oxford, I954), pp. 28-9. Robert P. Adams, “Bold bawdry and open manslaughter": the English new humanist attack on medieval romance', Huntington Library Quarterly 23 (1959), 33-48 makes a rare attempt to place the humanist condemnation of romance in its social and political context.

7 Putter and Gilbert, The Spirit of Medieval English Popular Romance, p. vii.

8 Arthur Johnston, Enchanted Ground: The Study of Medieval Romance in the 
Eighteenth Century (London, I964); John Ganim, 'The myth of medieval romance', in H. Bloch and S. G. Nichols (eds), Medievalism and the Modernist Temper (Baltimore, I996), pp. I48-66; Nick Groom, The Making of Percy's Reliques (Oxford, I999); David Matthews, The Making of Middle English, 1765-1910 (Minneapolis, I999).

9 Thomas Percy's three-volume Reliques of Ancient English Poetry was first published by James Dodsley on I4 February I765 after a two-and-a half years in the print shop; during this time Percy made ongoing changes to the contents of the volume and secured the Duchess of Northumberland as his dedicatee. The Reliques was an enormous and immediate success, attracting most famously the attention of Coleridge, Wordsworth and Sir Walter Scott; it ran to four editions in Percy's lifetime and more than fifty have been published since his death in I8I I. Groom's assessment of it as 'epoch-making' (The Making of Percy's Reliques, p. 3) is standard; J. M. P. Donatelli, 'Old barons in new robes: Percy's use of the metrical romances in the Reliques of Ancient English Poetry', in P. J. Gallacher and H. Damico (eds), Hermeneutics and Medieval Culture (Albany, I989), pp. 225-35 likewise urges that 'it changed the course of English literature' ( $\mathrm{p}$. 225). In addition to editing his 'reliques', Percy writes four essays, including one 'On the ancient and metrical romances' and a second 'On the ancient minstrels'; the former is the first piece of critical scholarship on the romances and contains the first bibliography of extant texts. Percy's inspiration for the Reliques was his acquisition c. I753 of the socalled Folio MS (now London, British Library, MS Additional 27879), a seventeenth-century commonplace book with an eclectic collection of romances, ballads and songs, most late medieval but almost all imperfect or corrupt. The contents of the manuscript have been edited by J. W. Hales and F. J. Furnivall, Bishop Percy's Folio MS, 4 vols (London, I86768); the most recent account of the manuscript is G. Rogers, 'The Percy folio manuscript revisited', in M. Mills et al. (eds), Romance in Medieval England (Cambridge, I991), pp. 39-64. Percy's judgement of romance is not, of course, wholly original; his observations are in part anticipated by Thomas Warton, Observations on the Faerie Queene (I764) and before that men like Richard Blackmore ('Essay on epic poetry', I7I6) and Richard Hurd (Letters on Chivalry and Romance, I762). What distinguishes Percy, apart from his unmatched popularity, and why I focus on him here is his reputation as an influential advocate of medieval popular romance; what I want to demonstrate is the extent to which such advocacy is, in the history of romance scholarship, invariably compromised.

Io Percy's inscription is printed in Hales and Furnivall, Bishop Percy's Folio Manuscript, vol. I, p. lxxiv.

I I Chaplain to the Northumberlands and author of their family history (a position he secured on the back of the Reliques' popular success), Percy was appointed in 1769 one of the King's Chaplains en route, via a deanship, to the bishopric of Dromore, Ireland. 
I2 The Correspondence of Thomas Percy and John Pinkerton, ed. Harriet Harvey Wood (New Haven, I985), p. Io.

I 3 Thomas Percy, The Reliques of Ancient English Poetry, 3 vol (London, I765), vol. 3, p. iii.

I4 Vicesimus Knox, Essays Moral and Literary, 2 vol (London, I782), vol. 2, p. $2 \mathrm{I} 4$.

I5 Percy, Reliques of Ancient English Poetry, vol. I, p. vi. Groom, The Making of Percy's Reliques, pp. 40-60 makes an energetic case for Percy's purposeful inclusion of violent, grotesque and salacious material. The Reliques 'welters in gore: the bloodiness of death and dismemberment incarnadines the entire three volumes, and if occasionally watered by humour or levity, it is more often deepened by a colossal amorality'; it is 'about eating, drinking, fornicating, singing, and killing' (pp. 45, 59).

I6 The Correspondence of Thomas Percy and Evan Evans, ed. A. Lewis (New Haven, I957), pp. 30-I.

I7 For a short account of the eighteenth-century vogue for primitivism and its social and political context see F. Stafford, 'Primitivism and the "primitive" poet: a cultural context for Macpherson's Ossian', in T. Brown (ed.) Celticism (Amsterdam, I996), pp. 79-96.

I 8 For an account of the nineteenth-century editions of the Reliques, I am indebted to Nick Groom's introduction to the facsimile edition of Reliques of Ancient English Poetry, 3 vols (Routledge, I996), vol. I, p. 54.

I9 George Ellis, Specimens of Early English Metrical Romances (London, I805).

20 The Letters of Sir Walter Scott, ed. H. J. C. Grierson, I2 vol (London, I932-37), vol. 3, p. 60.

2 I Southey's letter is cited in J. W. Robberds, Memoir of William Taylor, 2 vols (London, I843), vol. 2, p. 3 I.

22 The Miscellaneous Prose Works of Sir Walter Scott, 6 vols (Edinburgh, I 827), vol. 6, pp. I64-5, I86.

23 W. P. Ker, Epic and Romance: Essays on Medieval Literature (London, I 897), p. 37I.

24 Derek Pearsall, 'Understanding Middle English romance', Review 2 (I980), I05-25 (p.105).

25 Derek Pearsall, 'The development of Middle English romance', Mediaeval Studies 27 (I965), 9I-I I6 (pp. 9I-2, I04, I I4).

26 John Burrow, 'The uses of incognito: Ipomadon A', in C. Meale (ed.), Readings in Medieval English Romance (Cambridge, I994), pp. 25-34 (p. 34); Valerie Krishna, Five Middle English Arthurian Romances (New York, I99I), p. 24; Rogers, 'The Percy Folio manuscript revisited', p. 55; John Finlayson, 'Definitions of Middle English romance', Chaucer Review is (I980), 44-62, I68-8 I (pp. 59, I78). Donald B. Sands, Middle English Verse Romances (Exeter, I986), one of the most widely used student editions of the romances, provides a salutary reminder of how difficult it is for seasoned, let alone new, readers to escape the prejudicial judgements of past scholarship. Sands consistently characterises the Middle English 
romances he edits as 'pedestrian' and 'naive', 'grop[ing]' narratives that read 'much better the first time around than ... on the second or third'; at best 'one is hard put to say much against [them]', at worst, they exhibit 'the wrong-headed logic often attributed to children' (pp. 2, 5, I30, 350, 233).

27 Derek Pearsall and I. C. Cunningham (eds), The Auchinleck Manuscript (London, I977), p. ix; Dorothy Everett, Essays on Middle English Literature (Oxford, I955), p. I2; Andrew Taylor, 'Fragmentation, corruption, and minstrel narration: the question of the Middle English romances', YES 22 (1992), 38-62 (p. 58). Pierre Bourdieu, Distinction: A Social Critique of Taste, trans. R. Nice (London, I984), persuasively demonstrates the extent to which social hierarchies, and the ideologies that support and reproduce them, lie behind the aesthetic distinction between 'high' and 'low' art (the citation is from p. 7).

28 W. R. J. Barron, English Medieval Romance (London, I989), p. 5I.

29 The Correspondence of Percy and Pinkerton, p. Iо.

30 The Correspondence of Percy and Evans, p. IO2.

3 I Louise Fradenberg, "So that we may speak of them": enjoying the Middle Ages', New Literary History 28 (I997), 205-30 (pp. 207-9).

32 See, for instance, Pearsall, 'Middle English romance and its audiences', p. 42 and Sands, Middle English Verse Romances, pp. viii, I. Rosalind Field, 'Romance in England' in D. Wallace (ed.), The Cambridge History of Medieval English Literature (Cambridge, I999), pp. I52-76 cites Pearsall and argues that, given the contested nature of the genre, the only thing we can be sure about is 'the essentially recreational function of romance': '[i]t is entertainment for an audience; ... a successful romance is one which gives pleasure, whether or not accompanied by information or instruction' (pp. I 52-3).

33 C. D. Benson, The History of Troy in Middle English Literature (Woodbridge, I980), p. I34.

34 Sands, Middle English Verse Romances, p. vii.

35 Bourdieu argues that ' $\mathrm{t}$ ] he denial of lower, coarse, vulgar, venal, servile - in a word, natural - enjoyment, which constitutes the sacred sphere of culture, implies an affirmation of the superiority of those who can be satisfied with the sublimated, refined, disinterested, gratuitous, distinguished pleasures forever closed to the profane', Distinction, p. 7. See especially his chapters 'The aristocracy of culture' and 'Postscript' (pp. I2-96, 485-500).

36 Conscious of the complexity of both popular culture and the audience's agency in producing meaning from it, many modern theorists are increasingly uncomfortable with analysis that seeks to 'liberate' consumers from their own false consciousness; the stance of 'enlightenment', reproductive of the social and intellectual distinctions that have for so long marginalised the study of popular culture and stigmatised its audiences, is finally disabling. See, for instance, Jokes Hermes' introductory remarks to Reading Women's Magazines: An Analysis of Everyday Media Use (Cambridge, I995) and Janice Radway's revised introduction to the second 
edition of Reading Romance: Women, Patriarchy and Popular Literature (Chapel Hill, I99I).

37 Indebted to the work of Italian Marxist Antonio Gramsci - in particular his proposition that political hegemony is achieved by means of negotiation, whereby so-called dominant ideologies are not only in constant flux but are the product of a complex process of give-and take between dominant and subordinate groups - many cultural theorists have come to see popular culture as a site of contestation that is marked as much by resistance as incorporation. The virtue of what has come to be called NeoGramsci studies is that it acknowledges both the complexity of both popular culture and its consumers. For Gramsci's account of hegemony and how it works see 'Hegemony, Intellectuals and the State', anthologised in John Storey (ed.), Cultural Theory and Popular Culture; A Reader, 2nd edn (Harlow, I998), pp. 2 Iо-г6.

38 See for instance, Syr Tryamowre in Of Love and Chivalry: An Anthology of Middle English Romance, ed. J. Fellows (London, I993), line 3; Sir Eglamour of Artois, ed. F. E. Richardson, EETS o.s. 256 (London, I965), line 4; Emaré in The Middle English Breton Lays, eds A. Laskaya and E. Salisbury (Kalamazoo, I995), line 20.

39 For his provocative analysis of narrative desire and its mechanics, I am indebted to Peter Brooks, Reading for the Plot: Design and Intention in Narrative (Cambridge, MA, I992; first pub. New York, I984), especially pp. 37-6I.

40 Brooks, Reading for the Plot, p. 48.

4I Although Andrew Taylor has done much to debunk the romantic myth of the roaming minstrel who orally composes his romances and performs them to brutish illiterates in taverns and great halls ('The myth of the minstrel manuscript', Speculum 66 (I992), 43-73; 'Fragmentation, corruption, and minstrel narration: the question of the Middle English romances', YES 22 (I992), 38-62), some of the most innovative recent scholarship makes an informed case for renewed attention to romance's distinctively performative aesthetic. See, for instance, Nancy Mason Bradbury, Writing Aloud: Storytelling in Late Medieval England (Urbana, I998) and the work of performer-scholar Linda Marie Zaerr.

42 Barthes distinguishes between the text of jouissance (which 'unsettles the reader's historical, cultural, psychological assumptions') and the text of plaisir (which 'comes from culture and does not break with it'), but the distinction is neither rigid nor consistent. I want to propose instead that the two kinds of pleasure can be found in the same text and are not incompatible; in other words, we can enjoy the pleasure of happy endings while simultaneously challenging the assumptions that underpin those endings. See Roland Barthes, The Pleasure of the Text, trans. R. Miller (Oxford, I990; English trans. first pub. New York, I975), especially pp. $3^{-\mathrm{I}} 4$; the distinction between jouissance and plaisir is made most explicitly on p. I4. 